\title{
Using Education Informatics to Improve Library Services to Doctoral Students: An Embedded Approach
}

\author{
Lynette Ralph \\ Southeastern Louisiana University, Hammond, LA, USA
}

Iralph@selu.edu

\begin{abstract}
This paper discusses the use of Education Informatics in improving the quality of information literacy provided to doctoral students. As a discipline, Education Informatics is a combination of the disciplines of education, technology, and library science. The service of a librarian embedded in the course management system of one of the courses offered in a doctoral program served as the basis for this research. At the end of the course, an assessment was conducted of the service and the results confirmed that benefits could be gained from having a librarian available at the point of need. Easy accessibility to the librarian, the use of knowledge management, and customized services were some of the benefits identified by the students.
\end{abstract}

Keywords: Education Informatics, Embedded Librarian, Doctoral Students

\section{Introduction}

For more than a decade libraries have struggled to provide effective library training for both undergraduate and graduate students. While much of the focus has been on undergraduate students, usually, graduate students and specifically doctoral students are at a disadvantage because it is generally assumed that doctoral students are self-directed learners capable of independent research (Green \& Macauley, 2007). However, many researchers (Boote \& Beile, 2005; Tunon \& Ramirez, 2010) have acknowledged that very often doctoral students lack the requisite library research skills. These problems are enhanced when institutions are faced with serving doctoral students who also happen to be taking classes online or from a distance. Researchers Tunon and Ramirez (2010) assert that effective library service to doctoral students can be the difference between an ABD (All But Dissertation) and an EdD (Doctorate of Education). This article will discuss the efforts made to provide effective library services to the (EdD) students at Southeastern Louisiana University (Southeastern).

Material published as part of this publication, either on-line or in print, is copyrighted by the Informing Science Institute. Permission to make digital or paper copy of part or all of these works for personal or classroom use is granted without fee provided that the copies are not made or distributed for profit or commercial advantage AND that copies 1) bear this notice in full and 2) give the full citation on the first page. It is permissible to abstract these works so long as credit is given. To copy in all other cases or to republish or to post on a server or to redistribute to lists requires specific permission and payment of a fee. Contact Publisher@InformingScience.org to request redistribution permission.

\section{Background and Institutional Context}

Southeastern is located approximately 50 miles north of New Orleans. This university began in 1925 as a grass roots movement by the people of Hammond and the surrounding area. Southeastern has since grown to meet the evolving needs of southeast Louisiana and the 
Florida parishes and now has an enrollment of approximately 15,000. Southeastern is largely a commuter campus and is considered the second largest provider of distance education in Louisiana. In fall 2006, Southeastern added its first doctoral program in Educational Leadership, offered in consortium with the University of Louisiana-Lafayette (Southeastern Louisiana University Profile, 2006).

Graduate doctoral students at Southeastern in Educational Leadership need information literacy skills. The average graduate student in this group is returning to school after an extended period, and, therefore, lacks the appropriate sets of skills required to be successful. For example, these students use course readings, Google, and Wikipedia for their primary sources. Since these limited sources are inadequate, the students may begin the research process engaged and curious, but become frustrated and overwhelmed as it progresses. Additionally, Southeastern students are served in cohorts and do not have many opportunities to come to campus and, therefore, interact with other cohorts or have face to face contact with the librarian. The literature is replete with indications that the doctoral students are in need of more than the traditional one-shot Bibliographic Instruction (BI) (Li, 2007). They need periodic interaction with a librarian. The Embedded Librarian provides this opportunity.

Linus A. Sims Memorial Library (Sims) is a medium-sized academic library of Southeastern and serves as the main library of the campus. Each librarian serves as liaison to one or more academic departments on the campus. The purpose of the library liaison program is to build relationships with faculty members and provide personal communication about library sources, information literacy, and collection development. The library liaison program gives faculty a personal contact in the library and facilitates collaboration.

\section{The Problem}

Doctoral students are in need of more than just one-shot Bibliographic Instruction sessions (BIs). At Sims, several attempts were made to provide effective information literacy and library support to doctoral students. Initially, the Education liaison conducted orientation in the form of a onetime three-hour workshop during the second semester. When asked for feedback, the students revealed that, while this session was very helpful, they wished the information had been provided earlier. As a result, the timing of the one-shot three-hour workshop was adjusted to occur earlier by placing it in the first semester. However, the students acknowledged that some of the information presented at the time of the workshop was not yet needed and when it was needed, they had forgotten the information. The liaison and the faculty member then agreed to the addition of a question and answer session in the virtual classroom a few weeks after the workshop. This combination proved useful and facilitated the answering of questions and clarification of some concerns. However, the students still experienced periods when they needed access to librarians but their schedules simply did not permit this interaction. Because they were not on campus, these students could not take advantage of services such as Research Consulting where they could have a one-on-one session with a librarian.

The next attempt at improving library services for the doctoral students was to add the use of the virtual world of Second Life, after the virtual classroom session. While this also provided another opportunity to meet and interact virtually with the librarian and ask questions, it still did not meet the needs of the students who had burning questions at a time when no meeting was scheduled.

As Bergen and MacAdam point out, "Students prosper most from any form of library instruction when it comes at a time of greatest need and relevance to their academic work" (1985, p. 334). The Embedded Librarian was successfully used at Southeastern with a graduate nursing class (Guillot, Stahr, \& Meeker, 2010). After a discussion with the faculty of the Education Technology (Ed Tech) Class ETEC 695, the decision was made to implement the use of Education Informatics by having the liaison embedded in one course as a test. 


\section{Review of the Literature}

The Oxford English Dictionary defines Informatics as the branch of study that deals with the structure, properties, and communication of information and with means of storing or processing information. Other aspects of informatics include "the science of information" (Fourman, 2002), "understanding and promoting the effective organization, analysis, management, and use of information" (Agency for Healthcare Research and Quality, 2002); “a reliance of knowledge-based or evidence-based decision-making" (Wan, 2006, p. 333); and "facilitates the integration of data, information and knowledge” (American Nurses Association, 2008, p. vii). Definitions of informatics usually encompass the crossing of disciplines. Wan (2006) defines informatics as "an interdisciplinary science employing information on science, information technology and statistics" (p. 333). The American Nursing Association (2008), p. 1) points out that when applied to nursing, informatics "integrates nursing science, computer science, and information science to manage and communicate data, information, knowledge, and wisdom in nursing practice" (American Nurses Association, 2008, p.1). Informatics then focuses on the intersection of people, information, and technology systems.

The concept of Informatics originated in the mid-20th century (Blum \&Duncan, 1990; Collen, 1994) and while it emerged in medicine it has since been adopted by other disciplines including environmental science (Avouris \& Page, 1995), behavioral health (Dewan, Lorenzi, Riley, \& Bhattacharya, 2001), organizations (Beynon-Davies, 2002), community studies (Marshall, Taylor, \& Yu, 2003), social work (Parker-Oliver \& Demiris, 2006), social informatics (Kling, Rosenbaum, \& Sawyer, 2005), and nursing, public health, and bioinformatics (Wan, 2006), and Education (Collins \& Weiner, 2010; Stewart, 2000).

Stewart (2000) defined Education Informatics as "the collection, classification, storage, retrieval, and dissemination of recorded knowledge treated both as a pure and as an applied science" (p. 4). This definition is narrow because it focuses on the "recorded knowledge." However, Collins and Weiner (2010) expanded upon this definition and emphasized that from their perspective, Education Informatics would "incorporate new technologies and learning strategies to enhance the capture, organization, and utilization of information within the field of education" (p. 2524). Unlike Stewart, this definition centers on users of that knowledge and the information problems they experience. By focusing on the user, information problems can readily be identified, resulting in practical solutions and, therefore, providing incentives for the adoption of the solutions. From this writer's perspective, Education Informatics is the logical evolution of a blend of the disciplines of education, technology and information or library science.

In the case of Library Science, Information Technology is key to knowledge diffusion, but understanding and developing human interaction, human behavior, and information use and exchange are also essential (Pinelli \& Barclay, 1998). The fields of library and information science have a role to play in the development of Education Informatics. Although libraries have been traditionally based on a model of provision of documents and information, libraries can become oriented around problem identification and responding with solutions (Pinelli \& Barclay, 1998). For example, librarians are in a position to study user behavior of a variety of groups engaged in the education information-seeking process. They can be key to the development of new discovery systems, creating digital products, Web sites, and online help through tutorials, personal consultation, and collaborating with faculty to enhance course management systems. It is with this in mind that the writer proposed the use of Education Informatics for the improvement of library service to doctoral students. The method for implementing Educations Informatics was delivered through an Embedded Librarian service.

An Embedded Librarian has been described (Kesselman \& Watstein, 2009; Rudin, 2008; York \& Vance, 2009) as an intense integration of a librarian into a course where information literacy con- 
tent is recognized as an essential part of the curriculum and students have multiple opportunities for rich interactions with the librarian. A review of the literature indicates that librarians are increasingly embedding into courses and that such projects are usually successful. After reviewing a variety of programs and examples, Kesselman \& Watstein (2009) described Embedded Librarian programs as course integrated instruction and work on research collaborations. The Embedded Librarian allowed the author to be an active presence in the course, interacting with faculty and communicating information with students.

The library literature provides a wealth of information supporting collaboration of faculty and librarians in providing information literacy. O’Sullivan (2002) posits that information literacy skills have been taught for decades. But recently, the principles and concepts have assumed new urgency because they are increasingly perceived as significant "new economy" skills (p.7).

Rockman (2004) provided a number of case studies that document faculty and librarian collaboration to integrate library instruction into the curricula of various academic disciplines. McAskill (2008) points out that the rapid advances in information technology have led to greater pressure on academic librarians and teaching faculty to incorporate information literacy skills into the curriculum. Hollister (2008) discussed how librarian-faculty collaboration integrated library instruction into the University of Buffalo's world civilization curriculum.

The importance of the librarian-faculty collaboration cannot be overemphasized. It is critical to student success, and advantageous to everyone involved (Sugarman \& Thaxton, 2008). William Pannapacker, using his pseudonym, Thomas Benton, advocates the need for faculty to welcome collaboration more actively with librarians by expressing the following sentiments:

Apart from finding ways to foster collegiality, we as faculty members can work more efficiently with librarians to design research projects and to develop collection that support undergraduate curriculum. We can design assignments in consultation with librarians so it becomes impossible for students to pass through college without learning how to write a research paper ... accomplish any other goals that require the critical evaluation of sources (Benton, 2009).

Sims Library has encouraged librarian-faculty collaboration through participation in the liaison program. At Sims, the librarian liaisons are encouraged to communicate regularly with faculty, include faculty in the collection development and management process, and be familiar with the curriculum and faculty research interests. Williams (2010) suggests that these activities build strong relationships with faculty and establish collaborative partnerships. Both Whatley (2009) and Carpan (2011) emphasize that building partnerships is the essence of what it is to be a liaison librarian.

\section{Methodology}

The Evaluation of Instructional Technology Research (ETEC) 695 course at Southeastern is a basic course taken by students in the Master of Education and EdD. Several assignments in this course require students to conduct research in scholarly materials in the field of Ed Tech in the Department of Educational Leadership. Students in this program are encouraged to use library resources and services and to attend library orientations. It is one of the first courses taken by the doctoral student and seeks to provide them with the tools necessary for successful completion of the EdD. Upon completion of this course, each student should be able to, "locate, read and discuss examples of leading research and theory articles” (ETEC 695 syllabus, 2011). The initial meeting of this course revealed that the doctoral students were not equipped to effectively conduct library research and were in need of more than just the one-shot BI session. In the past, the Education Liaison had collaborated with the Ed Tech faculty in other information literacy attempts. It therefore seemed appropriate to continue the collaborative effort in this project. 


\section{Procedure for the Implementation of the Embedded Librarian Program}

The Education Library liaison for Educational Leadership was enrolled as a Teaching Assistant in the Ed Tech course in the Fall 2011. The Teaching Assistant role allowed the librarian to see course content and monitor discussion boards but did not allow the librarian to upload content. The librarian entered the online discussion board and opened the discussion by introducing herself and explaining her expected availability and involvement in the class. Students were then free to ask questions. The librarian responded to the students' questions with advice on databases and other resources including links to the sources and instructions on using them. The amount of time spent crafting responses varied; some responses were immediate, while others required more specialized research. Answering students' questions within the forum was only one type of service provided. The librarian also posted tips about finding and narrowing topics, information on preparing effective literature reviews, choosing and using library databases and resources, and incorporating research using American Psychological Association (APA) and Modern Language Association (MLA) styles, Reference Management Tools such as Endnote, Zotero, and Mendeley.

\section{Assessment of the Program}

To determine whether the service was successful, the librarian conducted a survey (see Appendix) using Survey Monkey. There were 10 students in the class and 10 students responded to the survey, a 100\% response rate. Five students (50\%) said they communicated with the Embedded Librarian via the Discussion Board, one via email, two via both email and the Discussion Board, and two did not communicate. When asked if they received satisfactory assistance, of the nine persons answering the question, eight (89\%) said "Always” and one (11\%) said "Sometimes." All 10 (100\%) students said they benefited from having an Embedded Librarian in the class. Two persons did not use the service. When asked why they did not use the service, they both admitted they could have used some help but did not ask for it. All 10 students recommended having an Embedded Librarian in future courses. In response to the question of how the service was helpful or unhelpful, eight persons responded, and they all indicated that the service was helpful. Their responses are delineated below:

- Librarian posted important information and I learned from the questions that other people asked.

- I got some resources for a paper I was writing.

- Finding articles relating to my research topic was difficult. The librarian was very helpful with narrowing down my search with keywords.

- She was able to help provide resources for my paper.

- The Embedded Librarian posted useful information such as information on The Lit Review Process - this was very helpful Also other students asked the question before I could and I benefited from the answer

- Very helpful because whenever I was stumped I could ask the Embedded Librarian and she always responded in a timely manner Enhanced my confidence

- She assisted me in other searchable key terms for my research project.

- She helped me locate resources for my research paper.

Finally, the students were asked to share any comments or suggestions regarding the service. Their responses are delineated below:

- The Embedded Librarian is definitely useful.

- I appreciated the assistance and having the librarian embedded in the course made it more convenient to ask for help. 
- This service was the best thing that happened to the class.

- Yes, I would definitely recommend having the Embedded Librarian in every course. As a doctoral student it is easy to feel isolated. Having the Embedded Librarian relieves this feeling. It feels personal It feels like someone cares.

\section{Advantages}

There were many advantages to using the Embedded Librarian. The most important was accessibility. The Librarian had more contact with students and provided more research information to them without requiring faculty members to give up more class time or the students to physically come to the library. In addition the information was strategically placed to coincide with the times students are ready to receive that information: when they are actually working on their research. If students had questions, the message board was available from within the course pages to seek help from the librarian.

Effective use of knowledge management is another advantage. Shank and Dewald (2003) point out that one of the advantages of hosting discussions online is that students benefit from the postings by and for other students. This proved to be true in this case as indicated by the students' comments in the survey.

The librarian was able to increase the visibility of Library resources and services by making students aware of resources that the library had recently purchased such as LibGuides.

The librarian was able to work with students on specific research-focused assignments thus ensuring customized resources for both students and faculty.

This service fostered collaboration between faulty and librarian. The importance of the librarianfaculty collaboration is irrefutable and critical to student success (Edwards, Kuman, \& Ochoa, 2010).

\section{Challenges}

While the program was successful, there were some challenges, for example, in the use of Email:

(a) Two students used email in lieu of using the discussion board. This defeated what the writer would describe as one of the basic knowledge management benefits of hosting discussions online so that other students could benefit from the postings by and for their peers. The librarian responded to the students' emails but requested that the student post the email on the discussion board. Both students complied.

(b) One of these two students used her own personal email, which is in contradiction to the university's policy. Here, the librarian answered the question but pointed out that the university established email must be used for all future email contact, and again reiterated the need to utilize the discussion board.

Establishing clear expectations of the role of the Embedded Librarian is another challenge. There were times when the students asked the librarian questions which were outside of her role. For example, one student asked the librarian permission to change her topic, while another sent the draft of her literature review and asked if she was on the right track.

Participating in the service was also very time-consuming. Because graduate students conduct their research in the evenings and on the weekends, many questions came in at that time. Fortunately, it was a small class and in this case, did not pose a significant hardship on the librarian. 


\section{Limitations and Future Considerations}

This research is limited because it reflects only one attempt to study one small group of ten doctoral students for a limited time. In future studies more doctoral students should have access to the Embedded Librarian in several courses. It would also be an advantage if these doctoral students could have access to the Embedded Librarian even after they have completed their course work and are working on their dissertation. As noted earlier, Tunon and Ramirez (2010) focus on the importance of having support for doctoral students at the point of need and emphasize that such support could be the determining factor in whether a student completes the degree.

Anecdotal feedback from the faculty member indicated that the Embedded Librarian service was extremely useful and greatly appreciated. She was very specific about the benefits of the service and clearly stated that the quality of the students' work was enhanced by the presence of the Embedded Librarian. As a result, at the time of the completion of this article, the Education Liaison is embedded in the Ed.Tech course currently offered. In the future, a formal interview should be conducted with the faculty member regarding her experiences and perceptions of the project. Questions should include her perceptions of the students' successful use of library resources and the ways in which the Embedded Librarian might have influenced the quality of the assignments.

\section{Conclusion}

The traditional one-shot bibliographic instruction session, even though still conducted, no longer meets the needs of providing information literacy to students enrolled in an intensive program such as a doctoral degree. The education liaison of Sims Library recognized the role that Education Informatics could play in improving the quality of service provided to the doctoral students. An important aspect of Education Informatics is the management and dissemination of existing knowledge and providing support at the time of need. Having an Embedded Librarian facilitated this process. Ultimately, Embedded Librarianship is about collaboration (Drewes \& Hoffman, 2010). Greater student success could be achieved with the collaboration of the librarian and the faculty member. This collaboration provides the graduate student with the facility "to find, evaluate, analyze, communicate and use information to solve problems, create new ideas, make informed decisions, and turn data into meaning” (Sugarman \& Thaxton, 2008).

At the end of the embedded period, the survey conducted revealed that both students and faculty benefited from the embedded librarian service and the students recommended that the service of an embedded librarian be implemented in all their courses. Overall, the service was a success and supported Bergen and MacAdam's point of view, as stated earlier, that "students prosper most from any form of library instruction when it comes at a time of greatest need and relevance to their academic work" (1985, p. 334).

\section{References}

Agency for Healthcare Research and Quality (AHRQ). (2002). Medical informatics for better and safer health care. Research in Action, 6. Retrieved from http://www.ahrq.gov/data/informatics/informatria.htm

American Nurses Association. (2008). Scope and standards of nursing informatics practice. Silver Spring, MD: American Nurses Association.

Avouris, N. M., \& Page, B. (Eds.). (1995). Environmental informatics: Methodology and applications of environmental information processing. Boston: Kluwer Academic.

Benton, T. H. (2009, August 7). A laboratory of collective learning. The Chronicle of Higher Education. Retrieved from http://chronicle.com/article/A-Laboratory-of-Collaborative/47518/

Bergen, K., \& MacAdam, B. (1985). One-on-one term paper assistance/programs. RQ, 24(3), 333-340. 


\section{Education Informatics}

Beynon-Davies, P. (2002). Information systems: An introduction to informatics in organizations. Bassingstoke, England: Palgrave.

Blum, B. I., \& Duncan, K. (1990). A history of medical informatics. New York: Addison Wesley.

Boote, D. N. \& Beile, P. (2005). Scholars before researchers: On the centrality of the dissertation literature review in research preparation. Educational Researcher, 34(16), 3-15.

Carpan, C. (2011). Library services in the age of Google: The importance of library liaison programs. College and Undergraduate Libraries, 18, 104-110. DOI: 10.1080/1069 1316.2011.550536.

Collen, M. F. (1994). The origins of informatics. Journal of the American Informatics Association, 1(2), 91-107.

Collins, J. W., \& Weiner, S. A. (2010). Proposal for the creation of a subdiscipline: Education Informatics. Teachers College Record, 112(10), 2523-2536.

Dewan, N. A., Lorenzi, N. M., Riley, R. T., \& Bhattacharya, S. R. (Eds.). (2001). Behavioral healthcare informatics. New York: Springer-Verlag.

Drewes, K., \& Hoffman, N. (2010). Academic embedded librarianship: An introduction. Public Services Quarterly, 6, 75-82.

Evaluation of Instructional Technology Research 695 Syllabus. (2011). Educational Leadership, Southeastern Louisiana University.

Edwards, M., Kuman, S. \& Ochoa, M. (2010). Assessing the value of embedded librarians in an online graduate educational technology course. Public Services Quarterly, 6, 271-291.

Fourman, M. (2002). Informatics research report EDI-INF-RR-0139. Retrieved from http://www.informatics.ed.ac.uk/

Green, R. \& Macauley, P. (2007). Doctoral students’ engagement with information: An AmericanAustralian perspective. Portal: Libraries and the Academy, 7(3), 317-332.

Guillot, L., Stahr, B., \& Meeker, B. (2010). Nursing faculty collaborate with embedded librarians to serve online graduate students. Journal of Library and Information Sciences in Distance Learning, 4(1/2), 53-62.

Hollister, C.V. (2008). Meeting them where they are: Library instruction for today's students in the world civilizations course. Public Services quarterly, 4(1), 15-27.

Kesselman, M. A., \& Watstein, S. B. (2009). Creating opportunities: Embedded librarians. Journal of Library Administration, 49(4), 383-400.

Kling, R., Rosenbaum, H., \& Sawyer, S. (2005). Understanding and communicating social informatics: A framework for studying and teaching the human contexts of information and communication technologies. Medford, N.J.: Information Today.

$\mathrm{Li}, \mathrm{H}$. (2007). Information literacy and librarian-faculty collaboration: A model for success. Chinese Librarianship, 24, 2. Retrieved from http://search.ebscohost.com

McAskill, W. (2008). Information literacy: The leadership role of the academic librarian. College Quarterly, 11(1), 1-15.

Marshall, S., Taylor, W., \& Yu, X. (Eds.). (2003). Using community informatics to transform regions. Hershey, PA: Idea Group.

O’Sullivan, C. (2002). Is information literacy relevant in the real world? Reference Services Review, 30(1), 7-14.

Parker-Oliver, D., \& Demiris, G. (2006). Social work informatics: A new specialty. Social Work, 51, 127134 
Pinelli, T. E., \& Barclay, R. O. (1998). Maximizing the results of federally-funded research and development through knowledge management: A strategic imperative for improving U.S. competitiveness. Government Information Quarterly, 15, 157-172.

Rockman, I. F. (2004). Integrating information literacy into the learning outcomes of academic disciplines. College and Research Libraries News, 64(9), 612-615.

Rudin, P. (2008). The evolution of outreach library services on university campuses. Reference Librarian, 49(1), 55-75.

Shank, J. D., \& Dewald, N. H. (2003). Establishing our presence in courseware: Adding library services to the virtual classroom. Information Technology and Libraries, 22(1), 38-43.

Southeastern Louisiana University Profile, (2006). The university of choice: Making a choice to expand.

Sugarman, T., \& Thaxton, M. L. (2008, June). Making it happen: librarian-faculty collaboration to improve student learning. Paper presented at the South Carolina Library Association. College \& University Annual Workshop. Retrieved from: http://works.bepress.com/tammy_sugarman/6

Stewart, R. G. (2000, November). Informatics as a field of study in education: A needs assessment and research agenda. Paper presented at the annual meeting of the Mid-South Educational Research Association, Bowling Green, KY.

Tunon, J., \& Ramirez, L. (2010). ABD or EdD? A model of library training for distance doctoral students. Journal of Library Administration, 50, 989-996. DOI: 10.1080/01930826.2010.489004

Wan, T. T. H. (2006). Introduction. International Journal of Public Policy, 1, 333-342.

Whatley, K. M. (2009). New roles of liaison librarians: A liaison's perspective. Research Library Issues, 265, 29-32.

Williams, K. (2010). Transforming liaison roles. Retrieved from: http://www.arl.org/rtl/plan/nrnt/nrntliaison.shtml

York, A. C., \& Vance, J. M. (2009). Taking library instruction into the online classroom: Best practices for Embedded Librarians. Journal of Library Administration, 49, 197-209.

\section{Appendix}

\section{The Embedded Librarian}

\section{Did you communicate with the Embedded Librarian via}

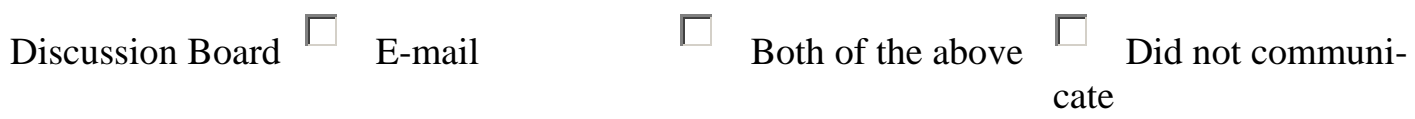

\section{Did you receive satisfactory assistance?}
Always
Sometimes
Never

\section{As a whole, did you benefit from having a librarian in your course?}

Yes

No 


\section{If you answered NO to question \#3, why not?}

I did not need to do research for this class

I already had the library research skills

I could have used some help but I did not ask for it

I asked for help but did not receive adequate answers

\section{How was it helpful or not helpful?}

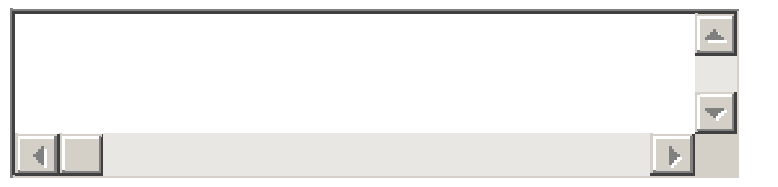

\section{Would you recommend having a librarian in future courses?}

Yes

No

\section{Please share any comments or suggestions you have regarding this service}

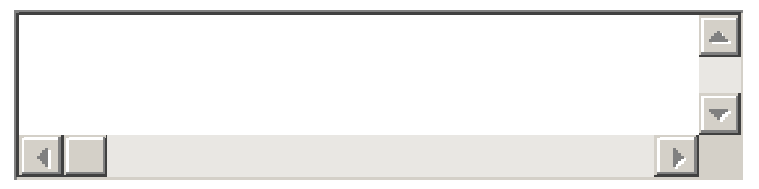

\section{Biography}

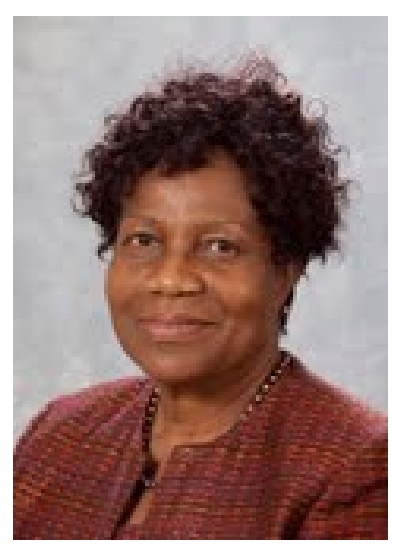

Dr. Lynette Ralph obtained a BA degree from the University of the West Indies (U.W.I.), an MS (Library \& Information Science) from Pratt Institute, an MPA from University of Baltimore, and a PhD in Information Science from Nova Southeastern University. Lynette currently serves as Assistant Library Director at Southeastern Louisiana University (Southeastern). Prior to joining Southeastern, Lynette served as Associate Director for Public Services at Mercer University, and Associate Director for Access Services at University of Maryland Health Sciences Library. Lynette's areas of interests include library administration, emerging technology, and effective and innovative methods of delivering library services. She is the author of Knowledge Management and Libraries: An Annotated Bibliography, and has published in several journals including College and Undergraduate Research Libraries, Journal of Information, Information Technology, and Organizations, Journal of Library Administration, and Electronic Journal of Academic and Special Librarianship. 